\title{
ENTROPY-SYNERGISTIC INTRODUCTION AS COMPREHENSIVE RESEARCH BASIS OF COMPLEX OBJECTS STATE
}

\author{
T. V. Kozulia, M. M. Kozulia* \\ National Technical University "Kharkiv Polytechnic Institute", 61002 Kharkiv, Ukraine
}

(Received September 14, 2018)

\begin{abstract}
The article deals with information support formation problem for comprehensive state assessment definition of research various nature object as a result of establishing compliance with safety requirements. The factors state stabilization analysis methods system and stationary communication of the "environment - object" is proposed. On information-entropy changes assessment basis by results of cognitive analysis of graphological models of system objects, cause-effect relationships are established for the influence manifestation between systems within object boundaries, external environment on object as a whole. Synergetics elements use for the essential mechanisms allocation in organizing order for selective instability and the regulation or arbitrary processes consolidation synchronization probabilistic manifestation in the interaction "environment - object" is proposed.
\end{abstract}

PACS: 519.713:631.411.6

\section{RELEVANCE OF SUBJECT, RESEARCH TASK}

Within the complex system information-entropy approach, complex systems evaluation with taking into account the entropy-synergistic mechanisms of reducing uncertainty, choice multiplicity is carried out not by the traditional probabilistic method, but is achieved through targeted programming of future, predetermined parameters and modes of given system functioning. For the main provisions formation of developed concept, important role is assigned to modern scientific knowledge in mathematics, physics, astronomy, information theory, synergetic, and others.

In works used to create an entropy-synergistic methodology for the complex study of complex objects, noted the necessity to apply mathematical aspects of information theory developed by A.M. Kolmogorov [1], to substantiate the complex reduction of uncertainty in the study of complex systems through the information capacity of various types of mathematical spaces. The task of managing information processes in this case relates to information interactions (relations) between the components of socioeconomic systems and subsystems, taking into account the peculiarities of their functioning and development.

For solving complex problems various matrixes of managerial decisions have been developed, which allow choosing the appropriate variants of system management according to probable situation changes with maximization of cooperative structure informa- tive that is the possibility of implementing systems interaction in direction of desired effects obtaining a positive option, system deviation from equilibrium - negative one. Estimation of changes and states set realization is carried out by information-entropy system analysis according to R. Hartley measure.

The Hartley measure is an informative level about system state $S_{\text {inf }_{\text {syst }}}$, indicating it as the level of compliance with requirements or changes in investigated object/system, taking into account system basis a with coding at $a$ certain length $d$ for number of all different combinations not less than $N$. In this case, the information-entropy state assessment is a reflection of states plurality (diversity as complexity and heterogeneity, which allows obtaining information about the reality of events), defined by R. Hartley formula, according to it pithiness:

$$
S_{\mathrm{inf}_{\mathrm{syst}}}=k \cdot \log _{a} N,
$$

where $k$ - coefficient of proportionality, scaling according to the chosen measure of investigated system base $a$.

Assessment complexity of complex systems quality is to establish structural organization conformity with its stated objectives and conditions flow of necessary processes. Correspondence as an effective evaluation of complex system state is established by introducing entropy function of state and changes of subject, object [2].

Thus, the problem arises of finding an informational support system for uniquely integrated evaluation of different nature research object as a result of information interaction between different sides and

\footnotetext{
*Corresponding author E-mail address: mariya.kozulya7@gmail.com
} 
an adequate reproduction of compliance with security system requirements.

\section{SUGGESTIONS AND RESULTS DISCUSSION}

Functionality is determined by processes flow therefore it should be characterized on the basis of special dynamism function of investigated system, namely on proposed correspondence entropy function. In system analysis of complex objects concept of entropy in the established order of their formation in the form of proposed structural matrices allows to establish system state "processes-functions", since entropy in change meaning, transformation according to systems thermodynamic theory reveals the measure of energy dissipation irreversibility.

Change direction in system "process-function" leads system object to stability due to synergy and establishment of certain energy internal environment level between its systems and stationary (equilibrium) with environment. Stability of received system object structure with considering processes proposed to evaluate on the basis of entropy-cognitive analysis with of stabilization, stability, management factors establishment. Developed cognitive map (CM) allows to reveal casual-effect links of influence manifestation within object framework on systems, components, etc. $[3,4]$.

For measurable and non-measurable coordinates of CM vertices as a state description of "environment (E) - system" (taking into account external perturbation, processes in system regarding the synergy of its stabilization, initial state) according to the entropy assessment, developed models of interrelated pulsed processes in this form:

$$
\begin{aligned}
\Delta \bar{S}^{\text {input }}(k+1) & =A \Delta \bar{S}^{\text {input }}(k)+ \\
& +D \Delta \bar{S}^{\text {output }}(k), \\
\Delta \bar{S}^{\text {output }}(k+1) & =C \Delta \bar{S}^{\text {output }}(k)+ \\
& +R \Delta \bar{S}^{\text {input }},
\end{aligned}
$$

where $\quad \Delta \bar{S}^{\text {input }}(k)=\bar{S}^{\text {input }}(k)-\bar{S}^{\text {input }}(k-1)$, $\Delta \bar{S}^{\text {output }}(k)=\bar{S}^{\text {output }}(k)-\bar{S}^{\text {output }}(k-1)$ - first differences; $A, B, C, D, R$ - weight adjacency matrixes.

In the first equation, model of the impulse process (1) has no measurable increments in the system $\Delta \bar{S}^{\text {output }}(k)$ are defined as limited disturbances for achievement of correspondence "E - system". For control in model introduced control vector as follows:

$$
\begin{aligned}
\Delta \bar{S}^{\text {input }}(k+1) & =A \Delta \bar{S}^{\text {input }}(k)+ \\
& +B \Delta \bar{U}(k)+D \Delta \bar{S}^{\text {output }}(k),
\end{aligned}
$$

where $\Delta \bar{U}(k)=-K \Delta \bar{S}^{\text {input }}(k)$ - vector control of state regulator, which reduces perturbation $\Delta \bar{S}^{\text {output }}(k)$

Cognitive matrix construction of interaction between object systems and self-organizing action processes involves the valuation of diverse and different dimensional information to modeling by the formula:

$$
\begin{array}{r}
b_{i j}=\frac{0.9\left(a_{i j}-\min _{i, j} a_{i j}\right)}{\max _{i, j} a_{i j}-\min i, j a_{i j}}, \\
i, j=[\overline{\overline{1,5}}] .
\end{array}
$$

In the course of studies on stability by initial data of input parameters and obtained impulse ratings using knowledge-oriented information established cause-effect relationships, give complex system behavior assessment and propose scientifically based strategy for priority development scenario realization. Synergetic elements inclusion allows to allocate more significant mechanisms of order organization for selective instability and the regulation or consolidation arbitrary processes of probabilistic manifestation of synchronization in the interaction of "E - object" due to synergetic ordering functions use - information, entropy, correlation concepts, bifurcation, etc. (Figure).

\section{CONCLUSIONS}

The information and methodological complex research in certain sequence of its realization allows to reveal self-organizing structures and processes (see Figure). According to the results of such complex assessments obtained self-organizing elements for achieving the goal (solving problems of stabilization, harmonization, obtaining a new quality), which will ensure:

- effective interaction with environment (ensuring object stability) - analysis methods of topological and cognitive models, entropy correspondences assessment;

- predictability state stability or change - cognitive analysis, comparative identification, manifestation probability assessment of destabilizing uncertainties - entropy-information assessment;

- support of arbitrary stabilization processes "E system" - thermodynamic changes analysis, entropy processes assessment;

- gaining knowledge about object "E - system". 


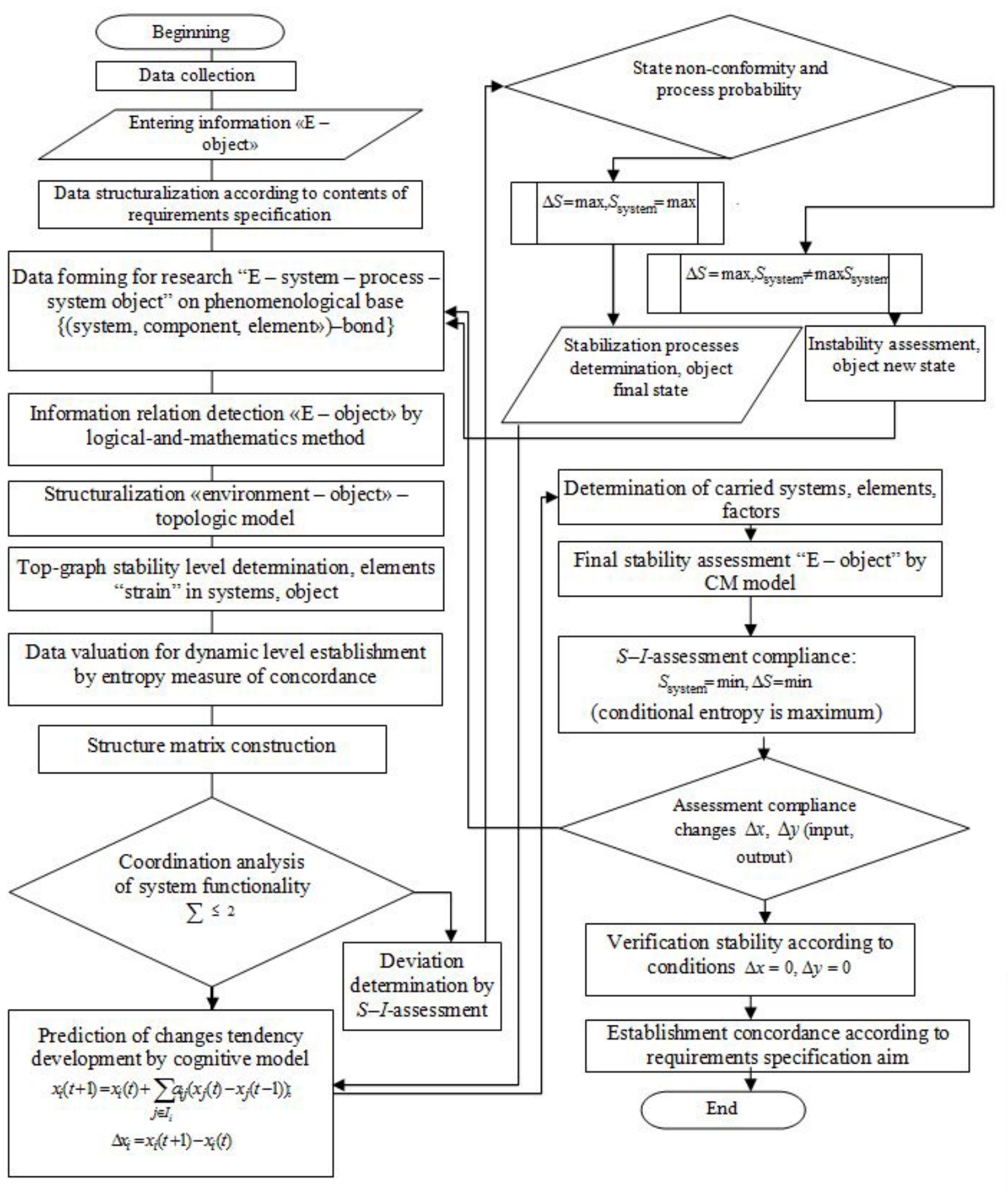

Algorithm schema of complex analysis system object state and establishment of regulated acts (management) for stabilization "environment - object"

\section{References}

1. A.N. Kolmogorov. Teorija informacii $i$ teorija algoritmov. M.: "Nauka", 1987, 304 p. (in Russian).

2. Ju.S. Popkov. Koncepcija jentropii v sistemnom analize. M.: Institut sistemnogo analiza RAN, 2014,48 p.

3. T.V. Kozulia. Teoretiko-prakticheskie osnovy metodologii kompleksnoj ocenki jekologichnosti territorial'nyh $i$ obektovyh sistem: Monografija. Saarbrüjcken: Palmarium Academic Publishing, 2014, 298 p. (in Russian).

4. T.V.Kozulia, M.A.Belova, M.M. Kozulia, N.G. Fonta. Informacionnoe obespechenie analiza bezopasnosti prirodno-tehnogennyh obektov $\mathrm{v}$ kontekste ih vzaimodejstvija s okruzhajushhej sredoj // International Scientific Journal. Tbilisi, 2016, v.3(56), p.72-81 (in Russian). 


\title{
ВНЕДРЕНИЕ ЭНТРОПИЙНО-СИНЕРГЕТИЧЕСКОЙ ОСНОВЫ КОМПЛЕКСНОГО ИССЛЕДОВАНИЯ СОСТОЯНИЯ СЛОЖНЫХ ОБЪЕКТОВ
}

\author{
Т. В. Козуля, М. М. Козуля
}

Рассмотрена задача формирования информационной поддержки определения комплексной оценки состояния объекта исследования разной природы как результат установления состояния требованиям безопасности. Предложена система методов анализа факторов стабилизации состояния и стационарности связи "окружающая среда - объект". На основе информационно-энтропийного оценивания изменений по результатам когнитивного анализа графологических моделей системных объектов устанавливаются причинно-следственные связи проявления влияния между системами на границах объекта, и влияния внешней среды на объект в целом. Предложено использование элементов синергетики для выделения существенных механизмов организации порядка для выборочной нестойкости и регулирования или упрочнения произвольных процессов вероятностного проявления синхронизации во взаимодействии "окружающая среда - объект".

\section{ЗАПРОВАДЖЕННЯ ЕНТРОПІЙНО-СИНЕРГІЙНОЇ ОСНОВИ КОМПЛЕКСНОГО ДОСЛІДЖЕННЯ СТАНУ СКЛАДНИХ ОБ'ЄКТІВ}

\section{Т. В. Козуля, М. М. Козуля}

Розглянута задача формування інформаційної підтримки визначення комплексної оцінки стану об'єкта дослідження різної природи як результат встановлення відповідності вимогам безпеки. Запропонована система методів аналізу факторів стабілізації стану та стаціонарності зв'язку "навколишнє середовище - об'єкт". На основі інформаційно-ентропійного оцінювання змін за результатами когнітивного аналізу графологічних моделей системних об'єктів встановлюються причинно-наслідкові зв'язки прояву впливу між системами в межах об'єкта та впливу зовнішнього середовища на об'єкт в цілому. Запропоновано використання елементів синергетики для виділення суттєвих механізмів організації порядку для вибіркової нестійкости та регулювання чи закріплення довільних процесів імовірнісного прояву синхронізації у взаємодії "навколишнє середовище - об'єкт". 